\title{
Role of the Receptor Tyrosine Kinase Axl and its Targeting in Cancer Cells
}

\author{
Cristina Corno ${ }^{\mathrm{a}}$, Laura Gatti ${ }^{\mathrm{a}}$, Cinzia Lanzi ${ }^{\mathrm{a},{ }^{*}}$, Nadia Zaffaroni ${ }^{\mathrm{a}}$, Diego Colombo ${ }^{\mathrm{b}}$ and \\ Paola Perego ${ }^{a, *}$
}

${ }^{a}$ Molecular Pharmacology Unit, Fondazione IRCCS Istituto Nazionale per lo Studio e la Cura dei Tumori, Milan, via Amadeo 42, 20133, Milan, Italy; ${ }^{b}$ Dipartimento di Biotecnologie Mediche e Medicina Traslazionale, Università degli Studi di Milano, Via Saldini 50, 20133 Milano, Italy

\begin{abstract}
Aberrant expression and activation of receptor tyrosine kinases (RTK) is a frequent feature of tumor cells that may underlie tumor aggressiveness. Among RTK, Axl, a member of the Tyro3-Axl-Mer family, represents a potential therapeutic target in different tumor types given its over-expression which leads to activation of oncogenic signaling promoting cell proliferation and survival, as well as migration and invasion. Axl can promote aggressiveness of various cell types through PI3K/Akt and/or MAPK/ERK, and its expression can be transcriptionally regulated by multiple factors. Deregulated Axl expression and activation have been shown to be implicated in reduced sensitivity of tumor cells to target-specific and conventional antitumor agents, but the precise mechanism underlying these phenomena are still poorly understood. Several small molecules acting as Axl inhibitors have been reported, and some of them are undergoing clinical investigation. In this review, we describe Axl biological functions, its expression in cancer and in drug-resistant tumor cells and the development of inhibitors tailored to this receptor tyrosine kinase.
\end{abstract}

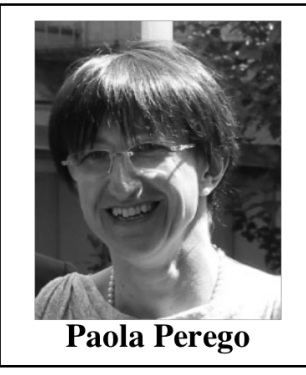

Keywords: Cancer, receptor tyrosine kinases, Axl, drug resistance, invasion, inhibitors.

\section{INTRODUCTION}

Cancer cells are characterized by a wide array of alterations which favour their survival and are ultimately implicated in tumor growth and progression [1]. Among them, the activation of RTK is frequent. Although the use of multiple molecular and biochemical approaches has led to the identification of alterations representing actionable targets for therapeutic intervention, the evidence of tumor heterogeneity, driven in part by clonal selection and cell plasticity, suggests that greater success could be achieved in the cure of cancer by striking crucial hubs. In this perspective, even the targeting of a single alteration may impact on multiple factors cooperating to maintain cell survival. Among the survival pathways involved in sustaining aggressive feature of tumor cells such as drug resistance and metastatic behaviour are PI3K/Akt/ mTOR and Raf/MEK/ERK, which regulate a variety of cellular

*Address correspondence to these authors at the Fondazione IRCCS Istituto Nazionale Tumori, via Venezian 1, 20133 Milan, Italy; Tel: +39-0223902237; Fax: +39-0223902692; E-mails: paola.perego@istitutotumori.mi.it, cinzia.lanzi@istitutotumori.mi.it processes including growth and metabolism [2, 3]. They are aberrantly activated in human tumors mainly due to inappropriate activation of RTK or mutations of pathway components.

RTK and other enzymes belonging to survival pathways represent important therapeutic targets given their role in trasducing physiological signals related to growth, adhesion, differentiation, motility and survival, from the extracellular environment to the nucleus [4]. Fifty-eight RTK have been identified in the human genome, grouped in 20 subfamilies based on the sequence homology $[5,6]$.

Several drugs developed to inhibit cell survival factors are tyrosine kinase (TK) inhibitors which interfere with the reaction catalysing the transfer of phosphate from high energy donor molecules (i.e., ATP) to substrates at tyrosine residues. The sensitivity of selected tumor types to specific TK inhibitors may reflect their dependence on a peculiar factor or pathway for survival, a relationship defined as "oncogene addiction" [7]. The available evidence suggests that the inhibition 
of a single RTK may not be sufficient to inhibit tumor growth in a persistent manner due to the cross-talk among different members of the RTK family (also referred to as RTK co-activation), a process which allows tumor cells to simultaneously activate two or more RTK due to the numerous transduced intracellular signals [8]. However, it appears that targeting of RTK crucial in sustaining multiple aspects of tumor cell aggressiveness may represent a promising strategy. In this context, Axl, a member of the Tyro3-Axl-Mer (TAM) family of RTK may constitute a valuable candidate to inhibit.

Here, we review the recent literature regarding Axl biological functions and the development of strategies to inhibit its function by pharmacological tools.

\section{PHYSIOLOGICAL ROLE OF AXL AND TAM RECEPTORS}

Originally isolated as transforming gene from primary human myeloid leukemia cells, Axl was cloned in the early nineties and identified as the prototype of a novel class of RTK by virtue of its kinase domain amino acid sequence and the juxtaposition of fibronectin type III and immunoglobulin-like repeats in the extracellular domain (Fig. 1) [9, 10]. The transforming capacity of the gene product, designated as Axl from "anexelekto", a greek word for "uncontrolled", was due to over-expression [9]. The human Axl gene is located on chromosome 19q13.2 and includes 20 exons. The gene is conserved among different organisms (e.g., mouse, rat, and non-human primates), and its role is not essential as supported by the observation that knockout mice are viable, without major development defects [11]. However, several pathological phenotypes can become evident in adult knockout mice, such as autoimmune diseases due to abnormal cytokine release, and accumulation of apoptotic cells and tissue necrosis [12]. Thus, Axl does not appear to be a key factor for embryogenesis, but it exerts extremely important functions in differentiated cells.

Axl appears to be a pleiotropic factor implicated in the regulation of multiple processes, even not related to cancer. Indeed, Axl signaling is involved in the regulation of the inflammatory response and has been recently linked to acute coronary syndrome [13]. Moreover, a role in immune activation of smooth muscle cells (SMC) in vein graft remodelling has been reported [14]. Such functions are consistent with the receptor expression in mammalian vascular and immune cells. Axl expression is ubiquitous, with expression in plate- lets, endothelial and renal cells, hepatocytes and macrophages, as well as in SMC, cardiac myocytes, testis and retina [4] as reported in the literature.

Besides Axl, two other genes, Tyro-3 and Mer, belong to the TAM RTK subfamily. They have unique expression profiles, with partial overlap (Table 1 [15]). Specifically, Tyro-3 is abundantly expressed in the nervous system, as well as in liver, skeletal muscle, osteoclasts, and retina [16-21]. Mer is expressed in monocytes/macrophages, dendritic cells, natural killer (NK) cells, megakaryocytes and platelets [16, 22]. High levels of Mer are also found in the testis, lung, retina, whereas lower expression is detected in brain, heart and skeletal muscle [21, 23]. The biological functions of TAM receptors are extremely diversified and depend on cell type and microenvironment; these receptors can play overlapping or cooperating roles [4], whose discussion is beyond the goal of the present review.

Among TAM receptors, Axl has emerged as a promising therapeutic target. In particular, it has been reported that Axl is over-expressed in many human tumors, including lung, colon, prostate and renal cancer $[4,24]$ and its oncogenic signaling promotes a variety of processes such as cell survival and proliferation as well as migration and invasion [25].

Many aspects of Axl signalling have been clarified early after its discovery, and a large body of data has been reported in the literature over the years contributing to build a complex view of the pathways acting downstream of Axl (see below).

\subsection{Axl Signaling and Expression Regulation}

Axl activation triggers a number of downstream events such as survival, proliferation, migration, adhesion and cytokine production, depending on the cell type and the microenvironment. Indeed, Axl has been implicated in the survival and migration of neurons in the central nervous system (CNS) [26], in the migration of SMC after vascular damage [27], in the differentiation and maturation of NK cells [28], and in the clearance of apoptotic cells, a process where macrophages and dendritic cells play an essential role [29,30].

The physiological ligand of Axl is Gas6 which binds the extracellular domain of the RTK, a phenomenon resulting in the receptor dimerization and subsequent trans-autophosphorylation of tyrosine residues in the cytoplasmic kinase domain. Thus, the enzyme phosphorylates multiple cellular substrates, forming various signaling complexes $[31,32]$. Three putative 
Axl

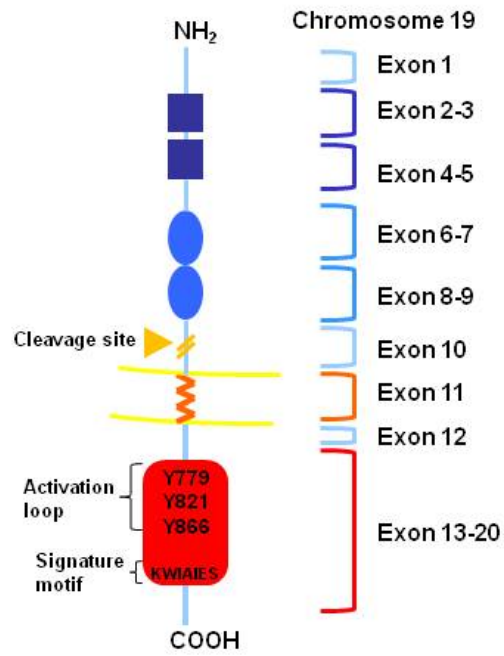

Immunoglobulin-like dom ain

Fibronectin type III dom ain

Transmembrane dom ain

Kinase dom ain
Mer

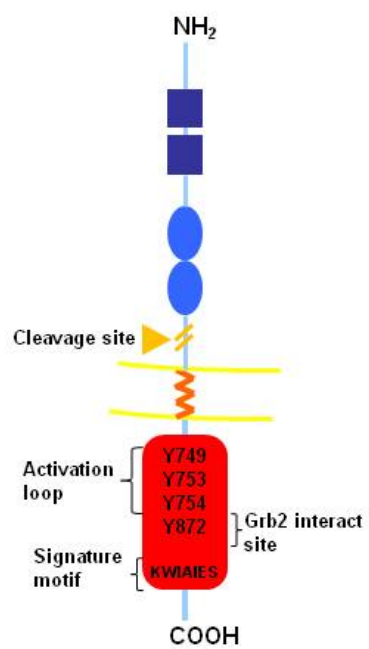

Tyro3

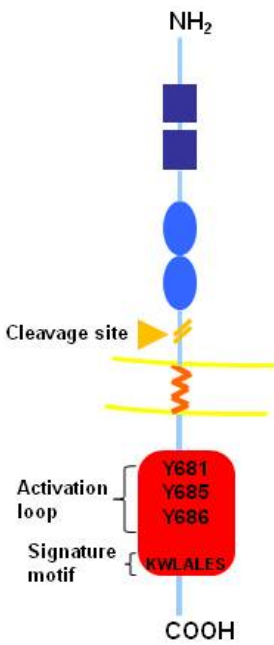

Fig. (1). Schematic representation of TAM receptor molecular structure. The different domains of the TAM Receptor Tyrosine Kinase (Axl, Mer, Tyro-3) are shown. The receptors are organized as follows: extracellular part with two imunoglobulinlike and two fibronectin-like domains, transmembrane and intracellular/kinase domains. Three putative autophosphorylation sites and conserved motifs, that characterize TAM receptor are indicated inside the kinase domain

Table 1. Expression of Axl, Tyro-3, Mer and of the Axl ligand Gas6 in normal tissues ${ }^{1}$.

\begin{tabular}{|c|c|c|c|c|}
\hline Cell type & Axl & Tyro-3 & Mer & Gas6 \\
\hline Endothelial cells & $+/-$ & $+/-$ & $+/-$ & $+/-$ \\
\hline Monocytes & $+/-$ & $+/-$ & $+/-$ & $+/-$ \\
\hline Denditic cells & $+/-$ & $+/-$ & $+/-$ & ++ \\
\hline Natural killers & $+/-$ & $+/-$ & $+/-$ & $+/-$ \\
\hline Whole blood & $+/-$ & $+/-$ & $+/-$ & $+/-$ \\
\hline Skeletal muscle & $+/-$ & + & ++ & $+/-$ \\
\hline Smooth muscle cells & +++ & $+/-$ & + & $+/-$ \\
\hline Cardiac myocytes & +++ & + & ++ & $+/-$ \\
\hline Adipocytes & + & $+/-$ & $+/-$ & ++ \\
\hline Placenta & ++ & $+/-$ & $+/-$ & $+/-$ \\
\hline Testis/Germ cells & ++ & $+/-$ & ++ & + \\
\hline Liver & $+/-$ & + & ++ & $+/-$ \\
\hline Kidney & $+/-$ & $+/-$ & $+/-$ & $+/-$ \\
\hline Lung & + & $+/-$ & + & +++ \\
\hline Brain & $+/-$ & ++ & + & $+/-$ \\
\hline Heart & $+/-$ & $+/-$ & ++ & ++ \\
\hline
\end{tabular}


(Table 1) contd....

\begin{tabular}{|c|c|c|c|c|}
\hline Cell type & Axl & Tyro-3 & Mer & Gas6 \\
\hline \hline Retina & ++ & $+/-$ & ++ & $+/-$ \\
\hline Ovary & $+/-$ & $+/-$ & $+/-$ & $+/-$ \\
\hline Prostate & $+/-$ & $+/-$ & $+/-$ & + \\
\hline
\end{tabular}

${ }^{1}$ The profile of expression in normal tissues/cells has been reported according to www.biogps.org [15]; +++ = high abundant expression; ++ = abundant expression; $+=$ moderate expression; $+/-=$ low expression.

auto-phosphorylation sites have been reported at the Cterminus of Axl, i.e, Y-779, Y-821, Y-866. The Y-821 residue has been shown to interact with phospholipase C, inositol-3-phosphate kinase and Grb2 [31,33]. Under physiological conditions, Axl activation is shut down through a variety of mechanisms including receptor endocytosis and ubiquitination, as well as dephosphorylation by tyrosine phosphatases, such as the $\mathrm{C} 1$-domain containing phosphatase and TENsin homologue (C1-TEN). In fact, C1-TEN1, which has been described as a negative regulator of the Akt signal transduction pathway inhibiting cell survival, proliferation, and migration $[34,35]$, has been reported to interact with Axl.

The extracellular portion of Axl can be cleaved off from the membrane to generate soluble Axl (sAxl) [36, 37]. The soluble fraction of Axl (65KDa) has been detected in human plasma and sera, as well as in conditioned media from cancer cells $[36,38]$. Morever, the levels of sAxl were correlated to poor prognosis in patients within renal cancer [39]. More recently, sAxl has been suggested as a possible circulating biomarker for Neurofibromatosis Type 1 related tumor burden [40]. The enzymes involved in the proteolytic cleavage of TAM receptors are still unknown. Cleaved Axl was proposed to bind Gas6 and to prevent receptor activation [37].

Once activated, Axl can promote growth and survival of various cell types, through different pathways including MAPK/ERK e PI3K/Akt. The activation of specific pathways is determined by both extracellular environment and cell tissue type in a context-dependent manner [25] (Fig. 2).

The relationship between Axl activation and MAPK pathway has been evidenced in different studies. Axl promotes cell proliferation via activation of Grb2 by direct binding with the Y-821 Axl residue [33]. Ligand-dependent Axl activation has been shown to stimulate MAPK, besides Akt and FAK pathways in Non Small Cell Lung Cancer (NSCLC) cell lines [41]. In these models, some Axl-dependent effects (i.e., clonogenic and tumorigenic abilities) were also observed upon Mer activation, suggesting a partially overlapping role for the two RTK in this cell context. A relevant role has been ascribed to the Axl/MAPK pathway in human gallbladder cancer cell lines, in which the transcriptional co-activator Yes-associated protein 1 (YAP1) and Axl were over-expressed [42]. In this study, a significant correlation was found between high expression of YAP1/Axl and poor prognosis, in keeping with the described transcriptional regulation of Axl expression by YAP1 [43]. Thus, in selected tumor types a direct link between Axl and Akt/ERK downstream pathways is clearly documented. In fact, YAP1 silencing switches off Axl activation and results in Akt and ERK dephosphorylation [42]. Of note, Axl was shown to be a relevant downstream target in YAP1dependent oncogenic functions also in hepatocellular carcinoma cell lines [44].

Besides, Axl has been described as direct transcriptional target of the Hippo pathway effector transcriptional co-activator with PDZ-binding motif (TAZ), which has been reported to contribute to gefitinib resistance of NSCLC cells harbouring epidermal growth factor receptor (EGFR)-T790M mutation [45].

Additional transcription factors have been implicated in regulating Axl expression in solid tumors (Fig. 3). The Sp1/Sp3 transcription factors have been linked to Axl constitutive expression; these proteins have been shown to bind GC-rich regions in the Axl promoter to upregulate its transcription, whereas methylation of $\mathrm{CpG}$ sites in Sp binding regions restricts Axl gene expression [46]. Over-expression of Myeloid Zinc Finger-1 (MZF-1) has been shown to result in Axl transactivation and to promote invasion in solid tumors, using in vitro and in vivo models [46, 47]. In addition, epigenetic regulation of Axl expression is supported by other studies. For example, transcriptional control of Axl has been proposed to occur in glioma cells through enhancer of zeste homolog 2 (EZH2), that is overexpressed in a variety of human cancers including glioma [48]. Such a factor controls epigenetic silencing of gene 


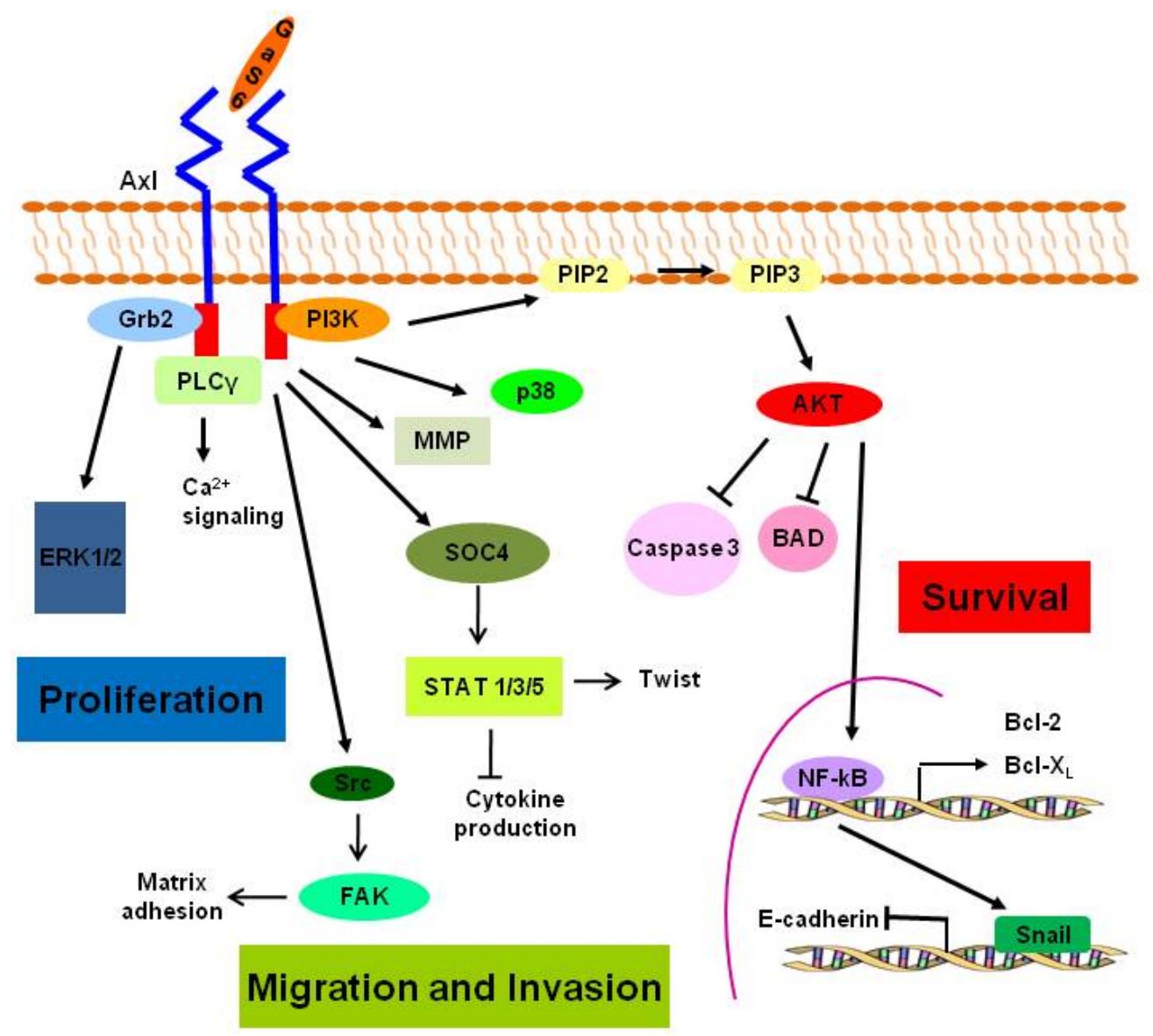

Fig. (2). Pathways downstream of Axl receptor. Schematic representation of cellular pathways activated down-stream of Axl receptor. Axl is implicated in regulating cell proliferation, migration, mainly through the activation of the canonical MAPK pathway $($ ERK1/2) and in cell survival via PI3K-Akt. Arrows stand for activating signals; $\stackrel{\perp}{\perp}$ stand for inhibitory signals.
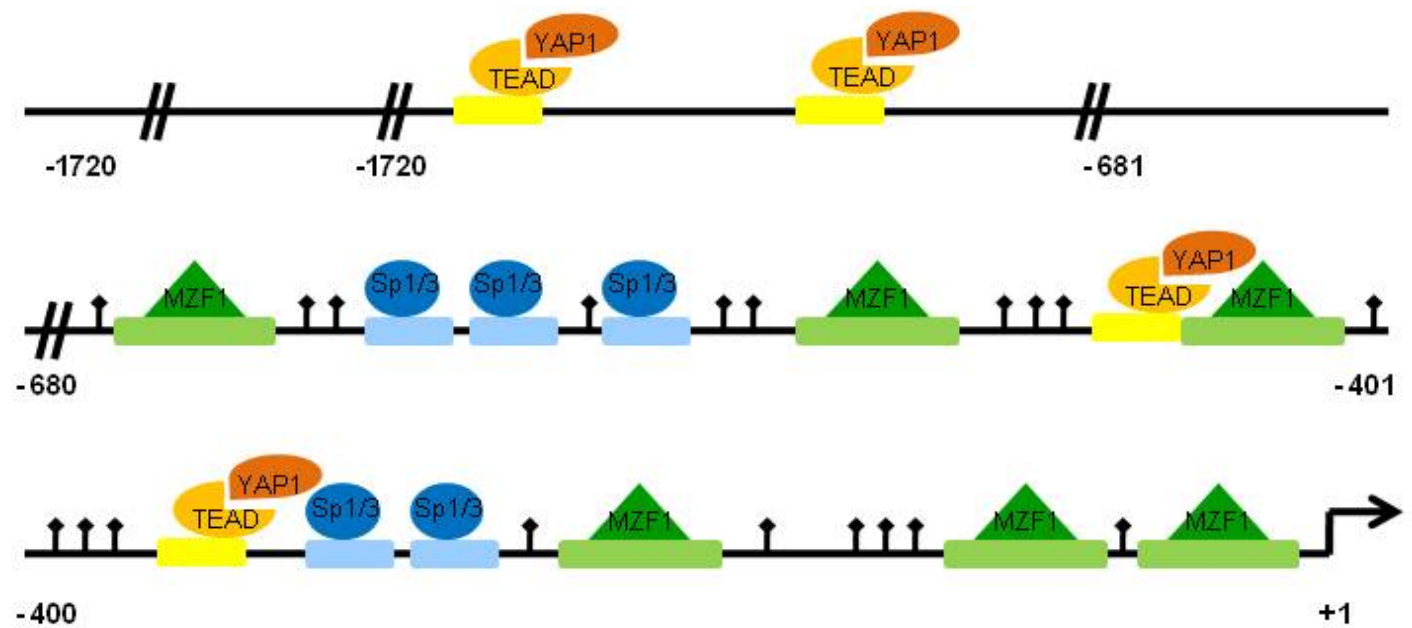

Fig. (3). Transcription factors involved in regulation of Axl expression in tumors. The arrows refer to $19 \mathrm{CpG}$ methylation sites within nucleotides -669 and -97 .

transcription through histone $\mathrm{H} 3$ lysine trimethylation acting as a silencer of tumor suppressor genes, thereby driving glioma malignancy via Axl transcription control.
Regulation of Axl levels has been also related to gain of function activities of mutant p53 in lung cancer cell lines [49]. In fact, mutant p53 enhanced the formation of acetylated histones on the Axl promoter. Of 
note, mutant p53 up-regulated the Axl promoter independently of $\mathrm{p} 53 / \mathrm{p} 63$ binding sites.

The available evidence supports that Axl activation, besides stimulating the MAPK/ERK pathways, results in PI3K/Akt stimulation, thereby leading to the expression of anti-apoptotic proteins. In this regard, NF-kB activation and nuclear translocation have been documented to increase the expression of anti-apoptotic proteins such as Bcl-2 e Bcl- $\mathrm{X}_{\mathrm{L}}$ and to inhibit proapoptotic factors such as caspase $3[50,51]$. Moreover, Gas6 triggers the phosphorylation of the pro-apoptotic protein Bad, a well known target of Akt, that maintains a survival signal when phosphorylated [52].

\section{AXL AND CANCER}

\subsection{Axl and Gas6 Expression in Tumors}

Although originally identified in chronic myelogeneous leukemia [9], the available literature supports that Axl is expressed in a variety of tumor types (Table 2). Gas6, the only activating Axl ligand has also been reported to be expressed in tumors and, in principle, may also be present in the tumor microenvironment (e.g. stroma cells).

\subsection{Regulation of Cell Aggressiveness}

Axl has been shown to contribute to the metastatic process, angiogenesis and cell survival in different experimental models through multiple pathways. A link between Axl expression and oxidative stress has been recently reported [53]. Using lung adenocarcinoma cell lines exhibiting different metastatic potential, it has been demonstrated that Axl activation elicits reactive oxygen species (ROS) accumulation through the oxidase-coupled small GTPase Rac1. Of note, Axl was activated by oxidative stress, leading to enhanced cell migration via the PI3K/Akt pathway. Akt1 targeting impaired hydrogen-peroxide induced migration and inhibited Rac1 activation, suggesting redox regulation in Axl-related malignant cell migration [53]. In addition, ROS-mediated Gas6 secretion has been reported as an early event of arginine auxotrophic response in cancer cells, where the auxotrophic challenge provides PI3K/Akt pathway activation and c-Myc protein stabilization as well as myc transcriptional induction, further supporting feedback mechanisms to enhance Axl expression [54].

Aberrant expression of Axl can lead to increased migration, thereby favouring invasion of tissues surrounding tumor cells [55]. The Axl kinase domain can mediate the binding with actin cytoskeleton, whereas
Table 2. Axl expression in different tumor types ${ }^{1}$.

\begin{tabular}{|c|c|}
\hline Tumor type & References \\
\hline Lung & $\begin{array}{c}{[41,45,49,82,83,84,88,90,} \\
91]\end{array}$ \\
\hline Breast & {$[55,80,103]$} \\
\hline Colon & {$[47,57]$} \\
\hline Liver & {$[44]$} \\
\hline Pancreas & {$[60]$} \\
\hline Kidney & [39] \\
\hline Melanoma & {$[77-79]$} \\
\hline $\begin{array}{c}\text { Cutaneous squamous cell can- } \\
\text { cer }\end{array}$ & {$[56]$} \\
\hline Glioblastoma & {$[48,63,66]$} \\
\hline Ovarian & {$[68,69]$} \\
\hline Prostate & {$[70]$} \\
\hline Esophageal squamous cell & [87] \\
\hline Head and neck & {$[81,87]$} \\
\hline Mesothelioma & {$[72-74]$} \\
\hline Osteosarcoma & {$[75,76]$} \\
\hline Gastrintestinal stromal (GIST) & {$[8]$} \\
\hline Myeloid leukemia & [9] \\
\hline Acute myeloid leukemia & [89] \\
\hline Chronic myeloid leukemia & {$[97]$} \\
\hline $\begin{array}{c}\text { Chronic lymphocytic leukemia } \\
\text { B cells }\end{array}$ & {$[101]$} \\
\hline
\end{tabular}

${ }^{1}$ The tumor subtypes mentioned in the review are reported. Gas6 is mentioned in Ref. [39, 63, 77].

the extracellular domain contains motifs which are important in the adhesion between cells $[4,26]$. Thus, the structural features of the receptor support its role in the establishment of cell-cell contacts. In this regard, it has been shown that Axl knockdown results in increased cell-cell attachment of cutaneous squamous cell carcinoma cells; this behaviour was associated with decreased expression of desmoplakin I in the cytoskeletal fraction, whereas desmoplakin II, plakoglobin, desmosomal cadherin and plakophilin expression levels remained unchanged. Moreover, cellular studies evidenced changes of the levels of components of tight junctions upon Axl knockdown (i.e., up-regulation of proteins of the zonula occludens and decrease of claudins) as well as up-regulation of E-cadherin - a component of adherent junctions - and increase membrane localization of plakoglobin, p120-catenin and 
alfa-catenin [56]. In addition, Axl depletion resulted in downregulation of Wnt and TGFbetaR signaling [56].

Axl has been shown to be constitutively phosphorylated in a human tumor subline derived from the colon carcinoma HCT116 cell line, exhibiting enhanced invasive ability [57]. This observation has led to the hypothesis that Axl may be implicated in epithelial to mesenchymal transition (EMT) [57], a finely regulated process, frequently occurring during tumor progression, that results in the acquisition of a pro-invasive phenotype coupled to strongly enhanced survival capabilities [58]. This process involves molecular, biochemical and cellular changes leading to an alteration of cell-cell and cell-matrix interactions, actin cytoskeletal reorganization, and activation of new transcriptional programs to maintain a mesenchymal phenotype [59]. In this context, Axl has been reported to control expression of Snail, Slug and Twist mRNA expression, which act as transcriptional repressors and play a key role in the phenotypic switch towards EMT [60].

Moreover, it has been shown that the migratory capability of Gas6 expressing vascular SMC was correlated with Axl kinase activity [61]. Thus, this receptor is likely to participate also in neo-angiogenesis which promotes tumor proliferation as Gas6/Axl downstream signaling favours cell survival.

Overall, it seems that increased Axl expression correlates with enhanced tumor cell invasive abilities, that are features associated with reduced patient survival [57]. Thus, by virtue of its contribution to tumor aggressiveness Axl represents a promising therapeutic target. Its pleiotropic biological role should be taken into account as a possible source of side effects in antitumor treatment based on Axl inhibition.

\subsection{Regulation of Cell Survival}

Axl expression has been shown to be altered in different tumor types, the oncogenic potential of the receptor being related to an aberrant regulation of cell survival. The TAM family of RTK is markedly expressed during the development of the CNS and deregulated activation of these RTK has been shown in different CNS-related disorders including brain tumors [62]. Several members of the RTK family have been proposed as promising therapeutic targets in glioblastoma multiforme (GBM), an aggressive form of brain tumor in which surgery, radiotherapy and temozolomide-based treatment fail to improve patient survival. Axl and its ligand Gas6 are frequently aberrantly expressed in human glioma and in vascular cells of neoplastic brain tissue, likely contributing to the poor clinical outcome of GBM patients [63]. The receptor and its ligand, frequently overexpressed in tumors, are likely to generate autocrine and paracrine stimulation loops. Moreover, given their pattern of co-expression, they appear to be involved in neo-vascularization of GBM. The role of Axl in maintaining the disease aggressiveness is also supported by its expression in stem-like GBM cells, particularly in those of the mesenchymal subtype, in which the receptor is expressed and phosphorylated, as evidenced by transcriptomic expression and kinome-wide short hairpin RNA screening [64]. The malignant phenotype of GBM appears to involve multiple members of the TAM family. In fact, in adult and paediatric glioblastoma cell lines, foretinib/XL880 (see paragraph 4.1), a RTK inhibitor currently undergoing clinical investigation, markedly inhibited Mer. The natural compound n-butylidenephtalide derived from Angelica sinensis has been found to display antitumor effects in vitro and in vivo, which are mediated by different mechanisms, including reduction of Axl expression in brain tumors [65]. Specifically, treatment with n-butylidenephtalide has been shown to result in decreased Axl expression, downregulation of matrix metalloproteinase activity and decreased expression of genes involved in EMT transition in GBM experimental models [65]. Of note, controlledrelease of the agent by a polymer wafer increased local drug concentration being active in situ in an intracranial tumor model of glioblastoma [66].

Axl has been shown to exhibit deregulated expression in ovarian carcinoma cells with acquired resistance to cisplatin [67], although a clear and univocal role for the kinase was not established. Of note, a marked fraction of Axl expressing tumors was identified among ovarian adenocarcinomas, particularly in G3 and stage III-IV tumors, Axl expression being a negative prognostic marker [68]. In a recent study, Axl signaling has been reported to converge on the integrin $\beta 3$ pathway and to induce tumor cell adhesion to the extracellular matrix and invasion in high grade epithelial ovarian cancer [69].

Gas6 has been reported to induce proliferation of prostate cancer cells expressing Axl [70]. In this context, the mitogenic effect was proportional to Axl expression and related to Akt and MAPK phosphorylation.

Exposure of tumor cells to apigenin (4',5,7trihydroxyflavone), a natural product of the flavonoid class, was shown to result in inhibition of the proliferation and clonogenic ability of NSCLC cell lines in as- 
sociation with a decrease of Axl mRNA and protein levels [71]. Since cell-cycle and apoptosis-related effects of apigenin appeared to be dependent on Axl levels, as they were modulated when Axl levels were increased or decreased using functional approaches, the RTK seems to be a relevant target of apigenin [71].

Co-activation of multiple RTK including Axl has been reported in mesothelioma cell lines in which the pro-apoptotic and anti-proliferative effects of the simultaneous inhibition of different kinases may be promising [72]. In fact, in this tumor type activation of the PI3K/Akt and Raf/MEK/MAPK pathways was shown to be dependent on the coordinated activation of EGFR, MET and Axl. Indeed, dual targeting of PI3K and $\mathrm{mTOR}$ pathways produced marked proliferation inhibition, suggesting a greater effect than inhibition of single kinases [67]. In keeping with this study, Ou WB et al. [73] reported that the combination of inhibitors of multiple RTK including Axl in mesothelioma cells together with targeting of the RTK chaperone HSP90, allowed to achieve a substantial inhibition of proliferation and survival. Over-expression of Axl was reported in primary specimens of pleural mesothelioma [74]. Over-expression, found in the majority of malignant pleural mesothelioma specimens, was shown to influence patient survival, independently of other established prognostic factors [74]. Axl has been proposed as a therapeutic target also in osteosarcoma, being among the most frequently activated RTK [75]. In keeping with this evidence, Gas6/Axl have been reported to inhibit apoptosis and to promote migration and invasion of osteosarcoma cells [76]. Increased expression of activated Axl has been related to recurrence and lung metastasis and Gas6/Axl were shown to predict clinical outcome in association with MMP-9 and Akt, but not ERK signaling [76]. Axl has been recently reported to be frequently expressed and to regulate cell proliferation and migration in melanoma cell lines, harbouring NRAS mutations [77, 78], where it has been identified as an activated RTK by proteomic approaches [78]. In a recent study, over-expression of Axl has been detected in different melanoma subtypes intrinsically resistant to BRAF inhibition [79].

\subsection{Axl and Drug Resistance}

Deregulated Axl expression and activation have been implicated in the reduced sensitivity of tumor cells to target-specific and conventional antitumor agents in different preclinical models.

Gastrointestinal stromal tumor (GIST) cells displaying acquired resistance to imatinib, a well known in- hibitor of Kit and PDGF receptor which have been implicated in the pathogenesis of GIST, have been found to exhibit Axl over-expression by virtue of a kinase switch [8]. Indeed, imatinib-resistant cells were characterized by reduced Kit and increased Axl expression. Since the Axl ligand was over-expressed in these cells, the kinase activation was the consequence of the presence of an autocrine loop. In breast cancer cells with acquired resistance to lapatinib, a potent and selective inhibitor of HER1 e HER2 widely used in the treatment of metastatic breast cancer, an association between lapatinib resistance and Axl over-expression was found [80]. In these cells, the mechanism leading to the receptor over-expression was linked to the promoter hypomethylation. Head and neck cancer cells with acquired resistance to the EGFR inhibitor erlotinib were characterized by Axl hyper-activation associated to enhanced migratory capability [81]. Such an observation is clinically relevant because high mRNA Axl levels were related to unfavourable prognosis in this tumor type [81]. In NSCLC, Axl activation was shown to confer resistance to EGFR targeting agents commonly employed in the treatment of patients bearing tumors with activating EGFR mutations [82]. Axl activation seems to be associated to erlotinib resistance in the absence of secondary EGFR mutations or activation of other RTK such as MET [82]. The relevance of Axl in such a tumor type is supported by in vitro and in vivo experiments showing that genetic and pharmacological inhibition of Axl can restore sensitivity to erlotinib [82]. In an additional report, evidence has been provided that Axl can contribute to drug resistance of cells treated with EGFR inhibitors, i.e. gefitinib and erlotinib. Indeed, using in vitro and in vivo preclinical models, combined exposure to erlotinib and to an Axl inhibitor could overcome resistance to the EGFR inhibitor through a marked impairment of EGFR downstream signaling [83]. Moreover, in another NSCLC cell line, Axl did not play any role in erlotinib resistance, underlying the complexity of the drug-resistant phenotype [84]. Recently, Axl silencing was shown to be unable to reverse erlotinib resistance in NSCLC cell lines. Since these cells underwent EMT, it appears conceivable that Axl inhibition is not sufficient to overcome resistance under such a condition [85]. A role for Axl in resistance to EGFR inhibitors is also confirmed by a study carried out in NSCLC clones and tumor xenograft models resistant to the EGFR targeting antibody cetuximab, which exhibit increased Axl expression and activation [86]. The cells appeared to be dependent on Axl for their proliferation through EGFR and down-stream signaling activation [86]. In fact, Axl 
stimulated cell proliferation, EGFR activation and MAPK signaling; furthermore, EGFR itself directly regulated Axl expression, creating a positive feedback loop to maintain the activation of EGFR by Axl. In preclinical models and clinical specimens, Axl overexpression was associated with resistance to PI $3 \mathrm{~K} \alpha$ inhibitors; of note, Axl expression and its interaction with EGFR were found to be associated also with resistance to PI3K $\alpha$ inhibitors and with persistent $\mathrm{PI} 3 \mathrm{~K} / \mathrm{Akt}$-independent mTOR activation in head and neck and esophageal squamous cell carcinomas [87]. Indeed, it has been demonstrated that Axl transactivates EGFR in a ligand-independent manner and induces its phosphorylation on Tyr1173, thus resulting in PLC $\gamma$ and PKC activation that, in turn, leads to a PI3K/Aktindependent $\mathrm{mTOR}$ activation. Therefore, the combined treatment with PI3K $\alpha$ inhibitors and either EGFR, Axl or PKC inhibitors was able to overcome acquired and intrinsic resistance to PI3K $\alpha$ inhibition in squamous cell carcinoma cells [87].

Little information is currently available regarding the role of Axl in resistance to conventional antitumor agents. Using a panel of different human tumor cell lines, a synergistic interaction between the antimitotic agent docetaxel and BGB324/R428 (see paragraph 4.1), the first-in-class and most specific Axl inhibitor, has been reported in cells with a mesenchymal phenotype, characterized by Axl expression. A favourable antitumor effect of the combination was also observed in in vivo models [85]. In this context, no synergistic interaction was found between the Axl inhibitor and cisplatin. However, a sensitization to docetaxel was observed in cells resistant to erlotinib and crossresistant to the taxane, upon Axl pharmacological inhibition [85]. Moreover, it has been shown that the green tea-derived catechin inhibited cell proliferation in association with down-regulation of $\mathrm{Axl}$ and Tyro3 expression in cisplatin-sensitive and -resistant NSCLC cells [88]. However, Axl role in this phenomenon has not been clearly defined, because no functional approaches were employed in the study. Using clinical samples from acute myeloid leukemia (AML) patients, it was found that Axl was the only factor over-expressed in chemotherapy refractory patients [89].

Axl overexpression in AML U937 cells resulted in the acquisition of a multidrug-resistant phenotype involving doxorubicin, cisplatin and etoposide only when cells were pre-treated with the Gas6 ligand [89]. Using proteomic approaches, MET, IGF, and Axl signaling have been identified as co-drivers of resistance to EGFR inhibitors besides mutant EGFR [90]. In a recent study, carried out in a cell line with acquired resistance to gefitinib, Axl overexpression has been shown to result from a slow turnover and defective degradation by presenilin-dependent intramembrane proteolysis [91]. Overall, the mechanisms leading to increased level of Axl in drug-resistant cells and tumors appear to be multiple.

\section{DEVELOPMENT OF AXL INHIBITORS}

\subsection{From Chemistry to Pharmacology}

A number of compounds with different chemical structures have been reported in the literature as being capable of inhibiting Axl (Table 3, Figs. 4 and 5). Under most circumstances, such compounds were developed to inhibit other kinases, and then found to be active on Axl. A general strategy that has been pursued to obtain kinase inhibitors is the synthesis of compounds able to bind the ATP binding site of the enzyme. It has been documented that this domain may exist in two different conformations, named "DGF-in" and "DGFout", related respectively to an active and to an inactive form of the enzyme and referring to the orientation (with respect to the active site) of a highly conserved sequence (Asp-Phe-Gly) placed in close proximity of a so called "activation loop" [92]. However just few kinases have been shown to exist in the latter conformation such as c-Abl which is stabilized in its "out" form by the binding with imatinib $[92,93]$. The conformational differences of the active site represent the basis of kinase inhibitors classification. Specifically compounds binding a kinase in its "DGF-in" form are named "type I inhibitors", conversely "type II" inhibitors bind the "DGF-out" form of the enzyme [94]. The active "DGF-in" conformation appears to be more conserved than the inactive "DGF-out" that shows higher variability among the kinases, thus type II are generally expected to be more selective than type I inhibitors even if this seems not to be a general rule [95].

Among the most relevant large spectrum inhibitors, recently reviewed by Feneyrolles et al. [25], are clinically approved drugs such as bosutinib/SKI-606, cabozantinib and sunitinib, besides foretinib/XL-880 and MGCD265, currently undergoing phase II evaluation [96]. Bosutinib is a second-generation dual Src/Abl TK inhibitor approximately ten times more potent than imatinib, which was recently approved by FDA and EMA as a second line option for CML treatment [97]. Four additional compounds are in phase I, namely BMS777607, LY2801653 (Merestinib), S49076 and BGB324/R428. In addition, TP0903 and SGI7079 have been reported as promising molecules emerging from preclinical studies, because their potency towards Axl 
Table 3. Axl inhibitors in preclinical or clinical development ${ }^{1}$.

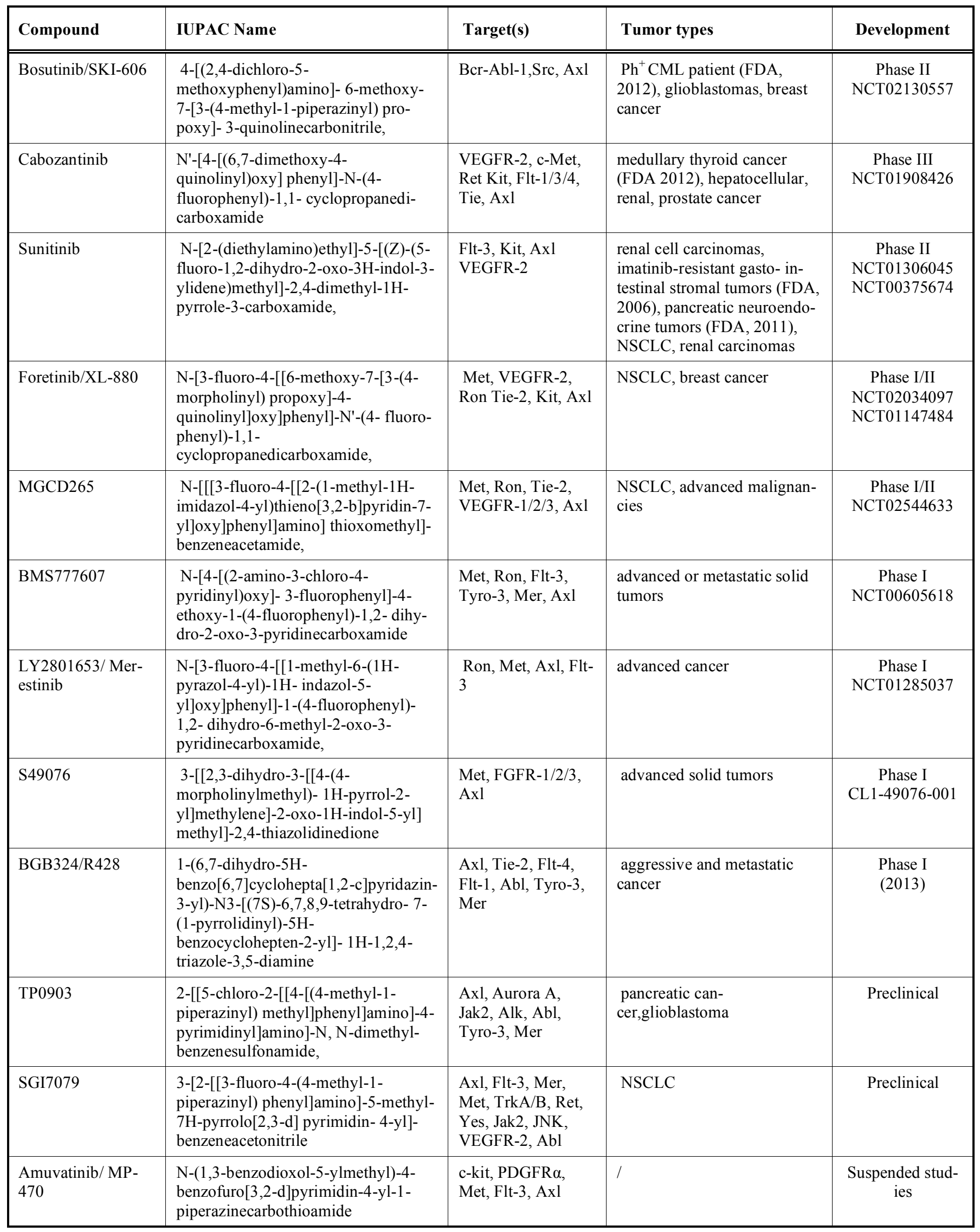


(Table 3) contd...

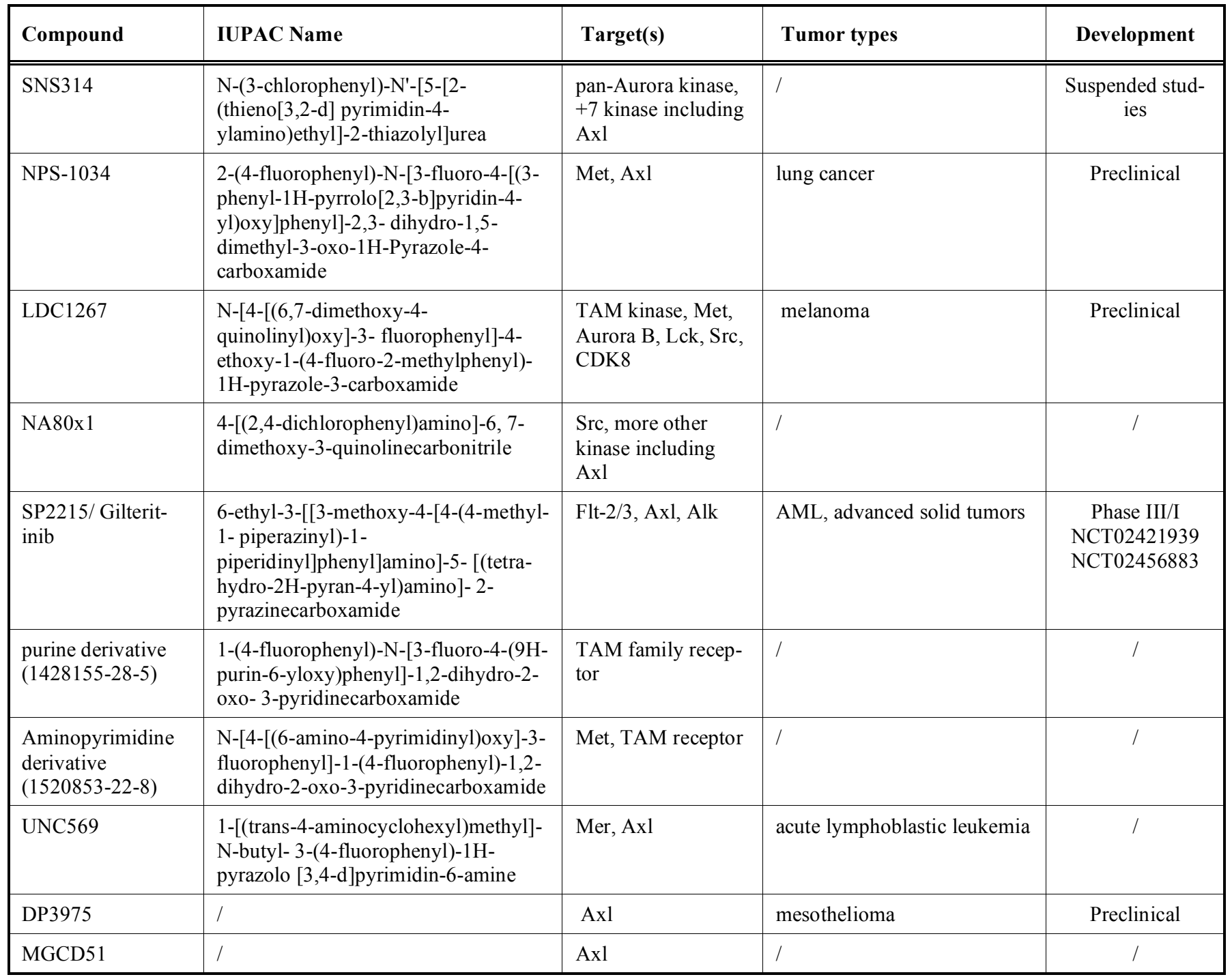

${ }^{1}$ The IUPAC names of the inhibitors are shown when available, besides the known targets, the tumor types where the compounds were studied and the development status. Trial reference id from ref 95 (https://clinicaltrials.gov).

appears to be in the nanomolar range in cell-free assays. A specific inhibition of Axl activation was also observed after exposure to the BGB324/R428 Axl inhibitor of two human GBM cell lines which resulted in survival and proliferation inhibition, and migration and invasion suppression [98]. The available evidence suggests that Tyro3 cooperates with Axl in sustaining aggressive features of tumor cells in these cellular models [98].

Amuvatinib/MP-470, an orally bioavailable synthetic carbothioamide, has already started the clinical evaluation due to its capability to inhibit mutant forms of RTKs (e.g. c-Met, Ret, c-Kit) and to suppress the induction of the DNA repair protein RAD51 in cell lines [99]. Results from a phase I trial suggested that the compound is well tolerated [100]. Interestingly,
Amuvatinib displays the capability to inhibit also Axl, its potency towards the target being in the micromolar range [25]. The Aurora Kinase pan-inhibitor SNS314, for which safety and tolerability studies have been carried out in patients [96], is described as capable of inhibiting Axl with an $\mathrm{IC}_{50}$ in the $\mathrm{nM}$ range. Although further effort is required to rank the selectivity of the available inhibitors, TP0903 and BGB324/R428 have been recognized as the most specific towards Axl [25], TP0903 being also promising for chronic lymphoid leukemia treatment due to its effect per se and in combination with BTK inhibitors in in vitro studies [101]. The above-mentioned multitargeted compounds [102] and also NPS-1034 [83], LDC1267, NA80x1 [103], MGCD516, ASP2215 (Gilteritinib), and DP3975 (the only one still under investigation at the preclinical 


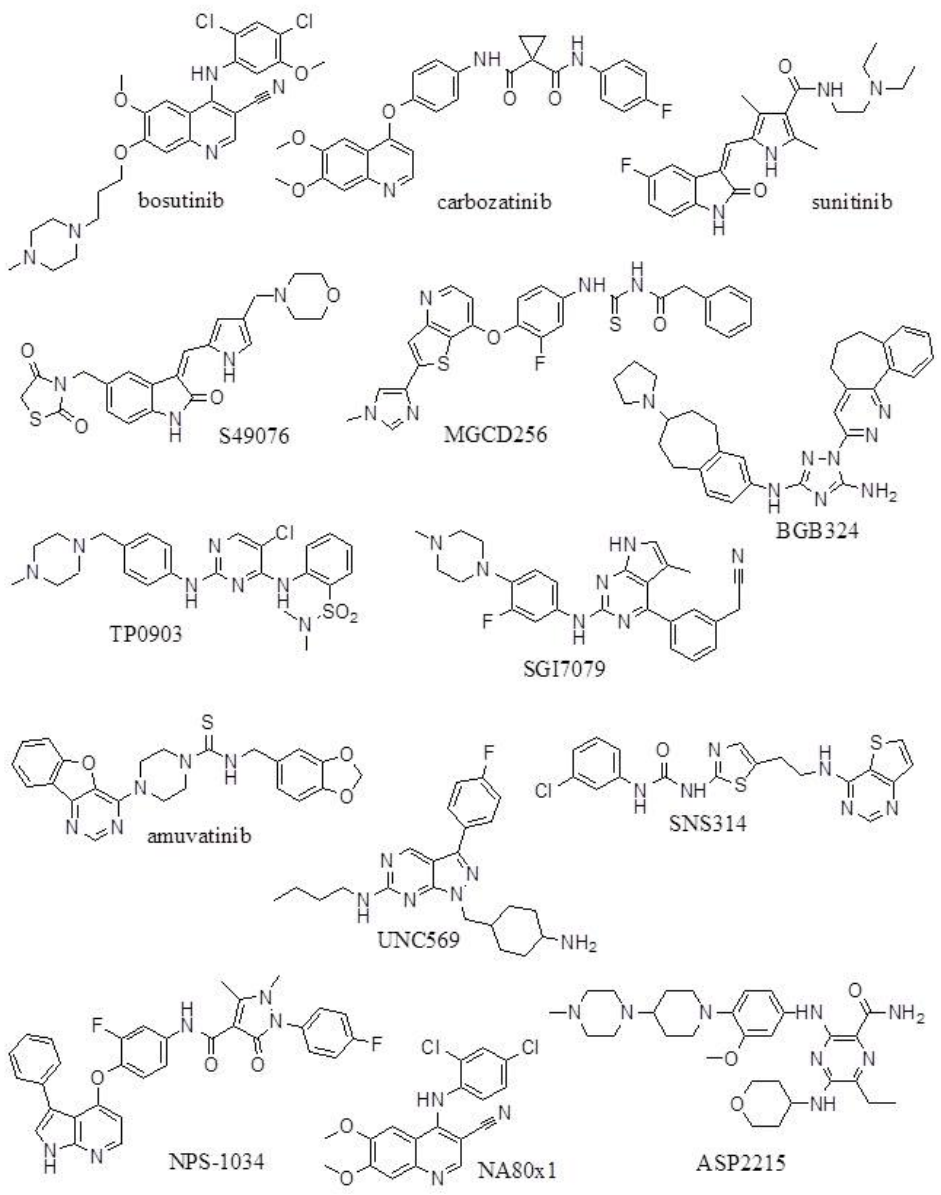

Fig. (4). Chemical structures of Axl inhibitors. The mentioned type I inhibitors of Axl with the exclusion DP3975 and MGCD516, whose structures are not available, are shown.
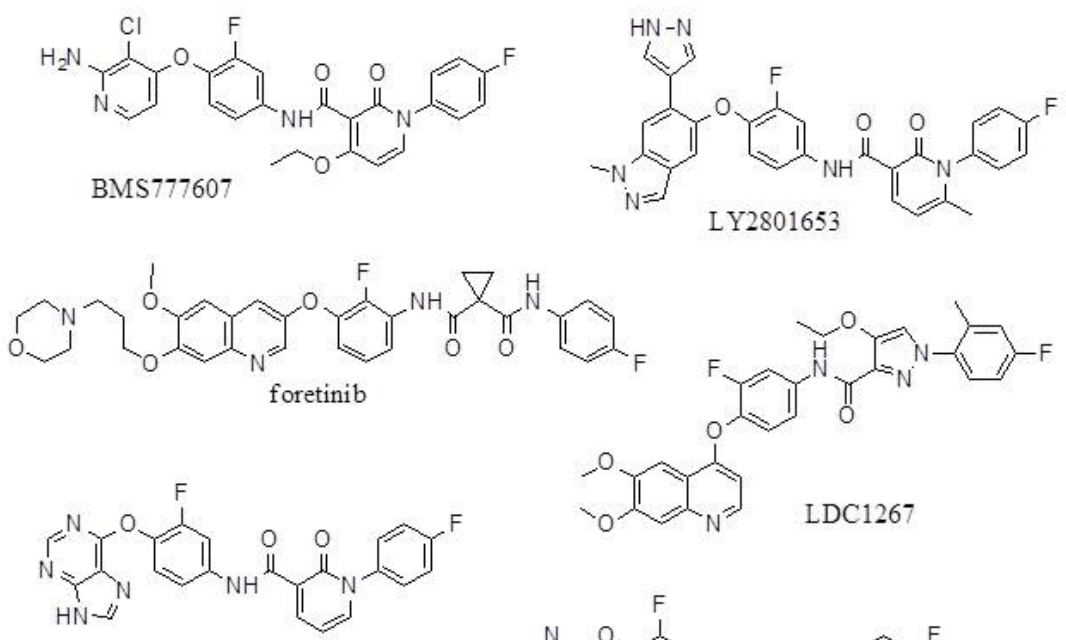<smiles>COc1cc2nccc(OC)c2cc1OC</smiles>

Purine analogue of BMS777607

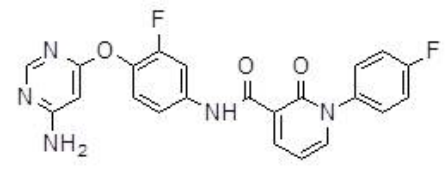

Pyrimidine analogue of BMS777607

Fig. (5). Chemical structures of Axl inhibitors. The mentioned type II inhibitors of Axl are shown.

level) are being evaluated in phaseI/II clinical trials. It has to be noted that the majority of the available kinase inhibitors are type I (Fig. 4) and, among the above mentioned inhibitors of Axl, only BMS777607, foretinib, LY2801653 [25, 104] and LDC1267 [105], are type II inhibitors (Fig. 5). 
The synthesis of inhibitors more selective for the TAM family has been recently reported. In particular, the type II BMS777607 was modified by replacing its pyridine with a purine [94] or with an aminopyrimidine [106] ring obtaining compounds with enhanced selectivity. In both cases, ring modification increased the selectivity towards TAM allowing the synthesis of likely type II inhibitors. The most active purine derivative (CAS Registry Number 1428155-28-5) together with one active aminopyrimidine derivative (CAS Registry Number 1520853-22-8) are shown in Fig. (5). The first one resulted to be a potent inhibitor of Axl and Mer, but remarkedly less active towards Tyro3. Efforts have also been made to study the selectivity of TAM inhibitors through computational approaches. Specifically, on the basis of experimental X-ray data available for c-Met kinase, Messoussi et al. [104] were able to identify the specific amino acids implicated in the binding of the inhibitors in both DFG-in and DFG-out conformations of Axl, Tyro3 and Mer kinases. The authors validated the obtained DFG-in and DFG-out homology models of the three TAM kinases by docking them with the type I UNC569, the first-in-class Merselective small molecule inhibitor (Fig. 4) [107] and type II BMS777607 inhibitors (Fig. 5). They also submitted to virtual screening 156 known TAM inhibitors (from public databases) docking most of them into the DFG-in model and only five into the DFG-out, finding that a terminal p-fluorophenyl group is crucial for type II inhibitors [10, 107]. Very recently, the pyrazolopyrimidine TAM inhibitor UNC569 [107] has also been used as a reference compound in a virtual screening study aimed at finding Mer kinase inhibitors [108], owing to its high resolution crystal structure in complex with the Mer kinase domain [107]. Of note, UNC569 was found to be effective against lymphoblastic leukemia in vitro and in vivo [109].

\section{CONCLUSION}

From the development of the first TK inhibitors which have been introduced into the clinical practice at the beginning of this century, many small molecules have been tested at the preclinical level, and new generations of inhibitors have been proposed. RTK represent amenable targets for therapeutic intervention and ATP competitive inhibitors are endowed with the potential to affect the function of multiple receptors of the family. In this regard, type II inhibitors have been hypothesized as being more selective. The use of RTK inhibitors in combination with conventional antitumor agents may also be promising, in view of the role of RTK and downstream pathways in sustaining multiple survival features of tumor cells, such as, for example, repair of drug-induced damage [3]. In addition, the acquired knowledge on the cross talk of different pathways driven by RTK supports that the simultaneous targeting of multiple RTK may be effective. This strategy appears to be promising also considering the occurrence of the activation of compensatory drug-resistance mechanisms preventing the action of RTK inhibitors in tumor cells. However, given the multiple physiological roles played by RTK, the development of selective inhibitors may be still pursued to minimize side-effects and it seems likely that the ongoing medicinal chemistry effort will lead to the optimization of small molecules specifically targeting selected kinases including Axl, through a new generation of type II inhibitors based on the availability of new protein crystal structures and related computational studies. Based on its biological role and recognized capability to control a plethora of cellular functions of tumor cells, Axl represents a valuable therapeutic target in different tumor types. In this regard, it has to be noted that Axl inhibition results in minimal toxicity although Axl role in limiting inflammation would suggest opposing antiinflammatory and oncogenic role for this kinase. Positive results from a phase Ia dose escalation study of BGB324 in healthy volunteers were presented at the 2014 AACR Annual Meeting, where it was shown that adverse effects were only grade 1 and were reversible, gastrointestinal events being the most common [110].

\section{LIST OF ABBREVIATIONS}

$\begin{array}{ll}\text { Akt } & \text { V-akt murine thymoma viral oncogene } \\ \text { homolog } & \text { acute myeloid leukemia. } \\ \text { AML } & \text { TENsin homologue } \\ \text { C1-TEN1 } & \text { central nervous system } \\ \text { CNS } & =\text { epidermal growth factor receptor } \\ \text { EGFR } & =\text { epithelial to mesenchymal transition } \\ \text { EMT } & =\text { Extracellular signal-regulated kinases } \\ \text { ERK } & =\text { glioblastoma multiforme } \\ \text { EZH2 } & \text { gastrointestinal stromal tumors } \\ \text { GBM } & \text { mitogen-activated protein kinase } \\ \text { GIST } & \text { Mitogen-activated protein kinase kinase } \\ \text { MAPK } & \text { Mammalian target of rapamycin } \\ \text { MEK } & =\text { Myeloid Zinc Finger-1 }\end{array}$




$\begin{array}{ll}\text { NK } & =\text { Natural Killer } \\ \text { NSCLC } & =\text { Non Small Cell Lung Cancer } \\ \text { PI3K } & =\text { Phosphoinositide-3-kinase } \\ \text { ROS } & =\text { reactive oxygen species } \\ \text { RTK } & =\text { receptor tyrosine kinases } \\ \text { SAXL } & =\text { soluble Axl } \\ \text { SMC } & =\text { smooth muscle cells } \\ \text { TAM } & =\text { Tyro3, Axl, Mer } \\ \text { TAZ } & =\text { transcriptional co-activator with PDZ- } \\ \text { TK } & =\text { tyrosine kinase } \\ \text { YAP1 } & =\text { Yes-associated protein } 1\end{array}$

\section{CONFLICT OF INTEREST}

The authors confirm that this article content has no conflict of interest.

\section{ACKNOWLEDGEMENTS}

The present work was in part supported by Associazione Italiana per la Ricerca sul Cancro (AIRC IG 15333), Milan, Italy, and by Fondazione I. Monzino.

\section{REFERENCES}

[1] Hanahan, D. and Weinberg, R.A. Hallmarks of cancer: the next generation. Cell, 2011, 144, 646-674.

[2] Cassinelli, G.; Zuco, V.; Gatti, L.; Lanzi, C.; Zaffaroni, N.; Colombo, D.; Perego, P. Targeting the Akt kinase to modulate survival, invasiveness and drug resistance of cancer cells. Curr. Med. Chem., 2013, 20, 1923-1945.

[3] Cossa, G.; Gatti, L.; Cassinelli, G.; Lanzi, C.; Zaffaroni, N.; Perego, P. Modulation of sensitivity to antitumor agents by targeting the MAPK survival pathway. Curr. Pharm. Des., 2013, 19, 883-894.

[4] Linger, R.M.; Keating, A.K.; Earp, H.S.; Graham, D.K. TAM receptor tyrosine kinases: biologic functions, signaling, and potential therapeutic targeting in human cancer. Adv. Cancer Res., 2008, 100, 35-83.

[5] Robinson, D.R.; Wu, Y.M.; Lin, S.F. The protein tyrosine kinase family of the human genome. Oncogene, 2000, 19, 5548-5557.

[6] Schlessinger, J. Receptor tyrosine kinases: legacy of the first two decades. Cold Spring Harb Perspect. Biol., 2014, 6, 10.1101/cshperspect.a008912.

[7] Torti, D. and Trusolino, L. Oncogene addiction as a foundational rationale for targeted anti-cancer therapy: promises and perils. EMBO Mol. Med., 2011, 3, 623-636.

[8] Mahadevan, D.; Cooke, L.; Riley, C.; Swart, R.; Simons, B.; Della Croce, K.; Wisner, L.; Iorio, M.; Shakalya, K.; Garewal, H.; Nagle, R.; Bearss, D. A novel tyrosine kinase switch is a mechanism of imatinib resistance in gastrointestinal stromal tumors. Oncogene, 2007, 26, 3909-3919.

[9] O'Bryan, J.P.; Frye, R.A.; Cogswell, P.C.; Neubauer, A.; Kitch, B.; Prokop, C.; Espinosa, R. III.; Le Beau, M.M.; Earp, H.S.; Liu, E.T. Axl, a transforming gene isolated from primary human myeloid leukemia cells, encodes a novel re- ceptor tyrosine kinase. Mol. Cell. Biol., 1991, 11, 50165031.

[10] Janssen, J.W.; Schulz, A.S.; Steenvoorden, A.C.; Schmidberger, M.; Strehl, S.; Ambros, P.F.; Bartram, C.R. A novel putative tyrosine kinase receptor with oncogenic potential. Oncogene, 1991, 6, 2113-2120.

[11] Lemke, G. and Lu, Q. Macrophage regulation by Tyro 3 family receptors. Curr. Opin. Immunol., 2003, 15, 31-36.

[12] Graham, D.K.; DeRyckere, D.; Davies, K.D.; Earp, H.S. The TAM family: phosphatidylserine sensing receptor tyrosine kinases gone awry in cancer. Nat. Rev. Cancer, 2014, 14, 769-785.

[13] Liu, Y.W.; Yang, Q.F.; Zuo, P.Y.; Xiao, C.L.; Chen, X.L.; Liu, C.Y. Elevated serum levels of soluble Axl in acute coronary syndrome. Am. J. Med. Sci., 2015, 349, 124-129.

[14] Batchu, S.N.; Xia, J.; Ko, K.A.; Doyley, M.M.; Abe, J.; Morrell, C.N.; Korshunov, V.A. Axl modulates immune activation of smooth muscle cells in vein graft remodeling. Am. J. Physiol. Heart Circ. Physiol., 2015, 309, H1048-58.

[15] BioGPS datasets. Available from: www.biogps.org (Accessed September 24, 2015).

[16] Angelillo-Scherrer, A.; de Frutos, P.; Aparicio, C.; Melis, E.; Savi, P.; Lupu, F.; Arnout, J.; Dewerchin, M.; Hoylaerts, M.; Herbert, J.; Collen, D.; Dahlback, B.; Carmeliet, P. Deficiency or inhibition of Gas6 causes platelet dysfunction and protects mice against thrombosis. Nat. Med., 2001, 7, 215-221.

[17] Katagiri, M.; Hakeda, Y.; Chikazu, D.; Ogasawara, T.; Takato, T.; Kumegawa, M.; Nakamura, K.; Kawaguchi, H. Mechanism of stimulation of osteoclastic bone resorption through Gas6/Tyro 3, a receptor tyrosine kinase signaling, in mouse osteoclasts. J. Biol. Chem., 2001, 276, 7376-7382.

[18] Lai, C.; Gore, M.; Lemke, G. Structure, expression, and activity of Tyro 3, a neural adhesion-related receptor tyrosine kinase. Oncogene, 1994, 9, 2567-2578.

[19] Lu, Q. and Lemke, G. Homeostatic regulation of the immune system by receptor tyrosine kinases of the Tyro 3 family. Science, 2001, 293, 306-311.

[20] Mark, M.R.; Scadden, D.T.; Wang, Z.; Gu, Q.; Goddard, A.; Godowski, P.J. rse, a novel receptor-type tyrosine kinase with homology to $\mathrm{Axl} / \mathrm{Ufo}$, is expressed at high levels in the brain. J. Biol. Chem., 1994, 269, 10720-10728.

[21] Prasad, D.; Rothlin, C.V.; Burrola, P.; Burstyn-Cohen, T.; Lu, Q.; Garcia de Frutos, P.; Lemke, G. TAM receptor function in the retinal pigment epithelium. Mol. Cell. Neurosci., 2006, 33, 96-108.

[22] Behrens, E.M.; Gadue, P.; Gong, S.Y.; Garrett, S.; Stein, P.L.; Cohen, P.L. The mer receptor tyrosine kinase: expression and function suggest a role in innate immunity. Eur. $J$. Immunol., 2003, 33, 2160-2167.

[23] Graham, D.K.; Dawson, T.L.; Mullaney, D.L.; Snodgrass, H.R.; Earp, H.S. Cloning and mRNA expression analysis of a novel human protooncogene, c-mer. Cell Growth Differ., 1994, 5, 647-657.

[24] GeneCards: The Human Gene Database. Available from: www.genecards.org (Accessed September 24, 2015).

[25] Feneyrolles, C.; Spenlinhauer, A.; Guiet, L.; Fauvel, B.; Dayde-Cazals, B.; Warnault, P.; Cheve, G.; Yasri, A. Axl kinase as a key target for oncology: focus on small molecule inhibitors. Mol. Cancer. Ther., 2014, 13, 2141-2148.

[26] Allen, M.P.; Zeng, C.; Schneider, K.; Xiong, X.; Meintzer, M.K.; Bellosta, P.; Basilico, C.; Varnum, B.; Heidenreich, K.A.; Wierman, M.E. Growth arrest-specific gene 6 (Gas6)/adhesion related kinase (Ark) signaling promotes gonadotropin-releasing hormone neuronal survival via extracellular signal-regulated kinase (ERK) and Akt. Mol. Endocrinol., 1999, 13, 191-201. 
[27] Melaragno, M.G.; Wuthrich, D.A.; Poppa, V.; Gill, D.; Lindner, V.; Berk, B.C.; Corson, M.A. Increased expression of Axl tyrosine kinase after vascular injury and regulation by $\mathrm{G}$ protein-coupled receptor agonists in rats. Circ. Res., 1998, 83, 697-704.

[28] Caraux, A.; Lu, Q.; Fernandez, N.; Riou, S.; Di Santo, J.P.; Raulet, D.H.; Lemke, G.; Roth, C. Natural killer cell differentiation driven by Tyro3 receptor tyrosine kinases. Nat. Immunol., 2006, 7, 747-754.

[29] Anderson, H.A.; Maylock, C.A.; Williams, J.A.; Paweletz, C.P.; Shu, H.; Shacter, E. Serum-derived protein S binds to phosphatidylserine and stimulates the phagocytosis of apoptotic cells. Nat. Immunol., 2003, 4, 87-91.

[30] Zagorska, A.; Traves, P.G.; Lew, E.D.; Dransfield, I.; Lemke, G. Diversification of TAM receptor tyrosine kinase function. Nat. Immunol., 2014, 15, 920-928.

[31] Braunger, J.; Schleithoff, L.; Schulz, A.S.; Kessler, H.; Lammers, R.; Ullrich, A.; Bartram, C.R.; Janssen, J.W. Intracellular signaling of the Ufo/Axl receptor tyrosine kinase is mediated mainly by a multi-substrate docking-site. Oncogene, 1997, 14, 2619-2631.

[32] Schlessinger, J. Cell signaling by receptor tyrosine kinases. Cell, 2000, 103, 211-225.

[33] Fridell, Y.W.; Jin, Y.; Quilliam, L.A.; Burchert, A.; McCloskey, P.; Spizz, G.; Varnum, B.; Der, C.; Liu, E.T. Differential activation of the Ras/extracellular-signalregulated protein kinase pathway is responsible for the biological consequences induced by the Axl receptor tyrosine kinase. Mol. Cell. Biol., 1996, 16, 135-145.

[34] Hafizi, S.; Ibraimi, F.; Dahlback, B. C1-TEN is a negative regulator of the Akt/PKB signal transduction pathway and inhibits cell survival, proliferation, and migration. FASEB J., 2005, 19, 971-973.

[35] Hafizi, S.; Alindri, F.; Karlsson, R.; Dahlback, B. Interaction of Axl receptor tyrosine kinase with C1-TEN, a novel C1 domain-containing protein with homology to tensin. Biochem. Biophys. Res. Commun., 2002, 299, 793-800.

[36] O'Bryan, J. P., Fridell, Y. W., Koski, R., Varnum, B., \& Liu, E. T. The transforming receptor tyrosine kinase, axl, is post-translationally regulated by proteolytic cleavage. $J$. Biol. Chem., 1995, 270(2), 551-557.

[37] Costa, M.; Bellosta, P.; Basilico, C. Cleavage and release of a soluble form of the receptor tyrosine kinase ARK in vitro and in vivo. J. Cellular Physiol., 1996, 168(3), 737-744.

[38] Ekman, C.; Stenhoff, J.; Dahlback, B. Gas6 is complexed to the soluble tyrosine kinase receptor axl in human blood. $J$. Thromb. Haemost., 2010, 8(4), 838-844.

[39] Gustafsson, A.; Bostrom, A.K.; Ljungberg, B.; Axelson, H.; Dahlback, B. Gas6 and the receptor tyrosine kinase axl in clear cell renal cell carcinoma. PloS One, 2009, 4(10), e7575.

[40] Johansson, G.; Peng, P.C.; Huang, P.Y.; Chien, H.F.; Hua, K.T.; Kuo, M.L. Soluble AXL: A possible circulating biomarker for neurofibromatosis type 1 related tumor burden. PloS One, 2014, 9(12), e115916.

[41] Linger, R.M.; Cohen, R.A.; Cummings, C.T.; Sather, S.; Migdall-Wilson, J.; Middleton, D.H.; Lu, X.; Baron, A.E.; Franklin, W.A.; Merrick, D.T.; Jedlicka, P.; DeRyckere, D.; Heasley, L.E.; Graham, D.K. Mer or Axl receptor tyrosine kinase inhibition promotes apoptosis, blocks growth and enhances chemosensitivity of human non-small cell lung cancer. Oncogene, 2013, 32, 3420-3431.

[42] Li, M.; Lu, J.; Zhang, F.; Li, H.; Zhang, B.; Wu, X.; Tan, Z.; Zhang, L.; Gao, G.; Mu, J.; Shu, Y.; Bao, R.; Ding, Q.; Wu, W.; Dong, P.; Gu, J.; Liu, Y. Yes-associated protein 1 (YAP1) promotes human gallbladder tumor growth via activation of the AXL/MAPK pathway. Cancer Lett., 2014, 355, 201-209.
[43] Liu, A.M.; Xu, M.Z.; Chen, J.; Poon, R.T.; Luk, J.M. Targeting YAP and Hippo signaling pathway in liver cancer. Expert Opin. Ther. Targets, 2010, 14, 855-868.

[44] Xu, M.Z.; Chan, S.W.; Liu, A.M.; Wong, K.F.; Fan, S.T.; Chen, J.; Poon, R.T.; Zender, L.; Lowe, S.W.; Hong, W.; Luk, J.M. AXL receptor kinase is a mediator of YAPdependent oncogenic functions in hepatocellular carcinoma. Oncogene, 2011, 30, 1229-1240.

[45] Xu, W.; Wei, Y.; Wu, S.; Wang, Y.; Wang, Z.; Sun, Y.; Cheng, S.Y.; Wu, J. Up-regulation of the Hippo pathway effector TAZ renders lung adenocarcinoma cells harboring EGFR-T790M mutation resistant to gefitinib. Cell Biosci., 2015, 5, 7-3701-5-7. eCollection 2015.

[46] Mudduluru, G. and Allgayer, H. The human receptor tyrosine kinase Axl gene--promoter characterization and regulation of constitutive expression by $\mathrm{Sp} 1, \mathrm{Sp} 3$ and $\mathrm{CpG}$ methylation. Biosci. Rep., 2008, 28, 161-176.

[47] Mudduluru, G.; Vajkoczy, P.; Allgayer, H. Myeloid zinc finger 1 induces migration, invasion, and in vivo metastasis through Axl gene expression in solid cancer. Mol. Cancer Res., 2010, 8, 159-169.

[48] Ott, M.; Litzenburger, U.M.; Sahm, F.; Rauschenbach, K.J.; Tudoran, R.; Hartmann, C.; Marquez, V.E.; von Deimling, A.; Wick, W.; Platten, M. Promotion of glioblastoma cell motility by enhancer of zeste homolog 2 (EZH2) is mediated by AXL receptor kinase. PLoS One, 2012, 7, e47663.

[49] Vaughan, C.A.; Singh, S.; Windle, B.; Yeudall, W.A.; Frum, R.; Grossman, S.R.; Deb, S.P.; Deb, S. Gain-offunction activity of mutant p53 in lung cancer through upregulation of receptor protein tyrosine kinase Axl. Genes Cancer, 2012, 3, 491-502.

[50] Demarchi, F.; Verardo, R.; Varnum, B.; Brancolini, C.; Schneider, C. Gas6 anti-apoptotic signaling requires NFkappa B activation. J. Biol. Chem., 2001, 276, 3173831744.

[51] Hasanbasic, I.; Cuerquis, J.; Varnum, B.; Blostein, M.D. Intracellular signaling pathways involved in Gas6-Axlmediated survival of endothelial cells. Am. J. Physiol. Heart Circ. Physiol., 2004, 287, H1207-H1213.

[52] Lee, W.P.; Wen, Y.; Varnum, B.; Hung, M.C. Akt is required for Axl-Gas6 signaling to protect cells from E1Amediated apoptosis. Oncogene, 2002, 21, 329-336.

[53] Huang, J.S.; Cho, C.Y.; Hong, C.C.; Yan, M.D.; Hsieh, M.C.; Lay, J.D.; Lai, G.M.; Cheng, A.L.; Chuang, S.E. Oxidative stress enhances Axl-mediated cell migration through an Akt1/Rac1-dependent mechanism. Free Radic. Biol. Med., 2013, 65, 1246-1256.

[54] Tsai, W.B.; Long, Y.; Park, J.R.; Chang, J.T.; Liu, H.; Rodriguez-Canales, J.; Savaraj, N.; Feun, L.G.; Davies, M.A.; Wistuba, I.I.; Kuo, M.T. Gas6/Axl is the sensor of arginineauxotrophic response in targeted chemotherapy with arginine-depleting agents. Oncogene, 2016, 35(13), 1632-1642.

[55] Li, Y.; Jia, L.; Ren, D.; Liu, C.; Gong, Y.; Wang, N.; Zhang, X.; Zhao, Y. Axl mediates tumor invasion and chemosensitivity through PI3K/Akt signaling pathway and is transcriptionally regulated by slug in breast carcinoma. IUBMB Life, 2014, 66, 507-518.

[56] Cichon, M.A.; Szentpetery, Z.; Caley, M.P.; Papadakis, E.S.; Mackenzie, I.C.; Brennan, C.H.; O'Toole, E.A. The receptor tyrosine kinase Axl regulates cell-cell adhesion and stemness in cutaneous squamous cell carcinoma. Oncogene, 2014, 33, 4185-4192.

[57] Dunne, P.D.; McArt, D.G.; Blayney, J.K.; Kalimutho, M.; Greer, S.; Wang, T.; Srivastava, S.; Ong, C.W.; Arthur, K.; Loughrey, M.; Redmond, K.; Longley, D.B.; Salto-Tellez, M.; Johnston, P.G.; Van Schaeybroeck, S. AXL is a key regulator of inherent and chemotherapy-induced invasion 
and predicts a poor clinical outcome in early-stage colon cancer. Clin. Cancer Res., 2014, 20, 164-175.

[58] Alexander, S. and Friedl, P. Cancer invasion and resistance: interconnected processes of disease progression and therapy failure. Trends Mol. Med., 2012, 18, 13-26.

[59] Radisky, D.C. Epithelial-mesenchymal transition. J. Cell. Sci., 2005, 118, 4325-4326.

[60] Koorstra, J.B.; Karikari, C.A.; Feldmann, G.; Bisht, S.; Rojas, P.L.; Offerhaus, G.J.; Alvarez, H.; Maitra, A. The Axl receptor tyrosine kinase confers an adverse prognostic influence in pancreatic cancer and represents a new therapeutic target. Cancer. Biol. Ther., 2009, 8, 618-626.

[61] Korshunov, V.A. Axl-dependent signalling: a clinical update. Clin. Sci. (Lond.), 2012, 122, 361-368.

[62] Pierce, A.M. and Keating, A.K. TAM receptor tyrosine kinases: expression, disease and oncogenesis in the central nervous system. Brain Res., 2014, 1542, 206-220.

[63] Hutterer, M.; Knyazev, P.; Abate, A.; Reschke, M.; Maier, H.; Stefanova, N.; Knyazeva, T.; Barbieri, V.; Reindl, M.; Muigg, A.; Kostron, H.; Stockhammer, G.; Ullrich, A. Axl and growth arrest-specific gene 6 are frequently overexpressed in human gliomas and predict poor prognosis in patients with glioblastoma multiforme. Clin. Cancer Res., 2008, 14, 130-138.

[64] Cheng, P.; Phillips, E.; Kim, S.H.; Taylor, D.; Hielscher, T.; Puccio, L.; Hjelmeland, A.B.; Lichter, P.; Nakano, I.; Goidts, V. Kinome-wide shRNA screen identifies the receptor tyrosine kinase AXL as a key regulator for mesenchymal glioblastoma stem-like cells. Stem Cell. Reports, 2015, 4, 899-913.

[65] Tsai, N.M.; Chen, Y.L.; Lee, C.C.; Lin, P.C.; Cheng, Y.L.; Chang, W.L.; Lin, S.Z.; Harn, H.J. The natural compound n-butylidenephthalide derived from Angelica sinensis inhibits malignant brain tumor growth in vitro and in vivo. $J$. Neurochem., 2006, 99, 1251-1262.

[66] Yen, S.Y.; Chen, S.R.; Hsieh, J.; Li, Y.S.; Chuang, S.E.; Chuang, H.M.; Huang, M.H.; Lin, S.Z.; Harn, H.J.; Chiou, T.W. Biodegradable interstitial release polymer loading a novel small molecule targeting Axl receptor tyrosine kinase and reducing brain tumour migration and invasion. Oncogene, 2016, 35(17), 2156-2165.

[67] Macleod, K.; Mullen, P.; Sewell, J.; Rabiasz, G.; Lawrie, S.; Miller, E.; Smyth, J.F.; Langdon, S.P. Altered ErbB receptor signaling and gene expression in cisplatin-resistant ovarian cancer. Cancer Res., 2005, 65, 6789-6800.

[68] Chen, P.X.; Li, Q.Y.; Yang, Z. Axl and prostasin are biomarkers for prognosis of ovarian adenocarcinoma. Ann. Diagn. Pathol., 2013, 17, 425-429.

[69] Rea, K.; Pinciroli, P.; Sensi, M.; Alciato, F.; Bisaro, B.; Lozneanu, L.; Raspagliesi, F.; Centritto, F.; Cabodi, S.; Defilippi, P.; Avanzi, G.C.; Canevari, S.; Tomassetti, A. Novel Axl-driven signaling pathway and molecular signature characterize high-grade ovarian cancer patients with poor clinical outcome. Oncotarget, 2015, 6(31), 30859-30875.

[70] Sainaghi, P.P.; Castello, L.; Bergamasco, L.; Galletti, M.; Bellosta, P.; Avanzi, G.C. Gas6 induces proliferation in prostate carcinoma cell lines expressing the Axl receptor. $J$. Cell. Physiol., 2005, 204, 36-44.

[71] Kim, K.C.; Choi, E.H.; Lee, C. Axl receptor tyrosine kinase is a novel target of apigenin for the inhibition of cell proliferation. Int. J. Mol. Med., 2014, 34, 592-598.

[72] Zhou, S.; Liu, L.; Li, H.; Eilers, G.; Kuang, Y.; Shi, S.; Yan, Z.; Li, X.; Corson, J.M.; Meng, F.; Zhou, H.; Sheng, Q.; Fletcher, J.A.; Ou, W.B. Multipoint targeting of the $\mathrm{PI} 3 \mathrm{~K} / \mathrm{mTOR}$ pathway in mesothelioma. $B r . J$. Cancer, 2014, 110, 2479-2488.

[73] Ou, W.B.; Hubert, C.; Corson, J.M.; Bueno, R.; Flynn, D.L.; Sugarbaker, D.J.; Fletcher, J.A. Targeted inhibition of multiple receptor tyrosine kinases in mesothelioma. Neoplasia, 2011, 13, 12-22.

[74] Pinato, D.J.; Mauri, F.A.; Lloyd, T.; Vaira, V.; Casadio, C.; Boldorini, R.L.; Sharma, R. The expression of Axl receptor tyrosine kinase influences the tumour phenotype and clinical outcome of patients with malignant pleural mesothelioma. Br. J. Cancer, 2013, 108, 621-628.

[75] Rettew, A.N.; Getty, P.J.; Greenfield, E.M. Receptor tyrosine kinases in osteosarcoma: not just the usual suspects. Adv. Exp. Med. Biol., 2014, 804, 47-66.

[76] Han, J.; Tian, R.; Yong, B.; Luo, C.; Tan, P.; Shen, J.; Peng, T. Gas6/Axl mediates tumor cell apoptosis, migration and invasion and predicts the clinical outcome of osteosarcoma patients. Biochem. Biophys. Res. Commun., 2013, 435, 493500 .

[77] Sensi, M.; Catani, M.; Castellano, G.; Nicolini, G.; Alciato, F.; Tragni, G.; De Santis, G.; Bersani, I.; Avanzi, G.; Tomassetti, A.; Canevari, S.; Anichini, A. Human cutaneous melanomas lacking MITF and melanocyte differentiation antigens express a functional Axl receptor kinase. $J$. Invest. Dermatol., 2011, 131, 2448-2457.

[78] Tworkoski, K.A.; Platt, J.T.; Bacchiocchi, A.; Bosenberg, M.; Boggon, T.J.; Stern, D.F. MERTK controls melanoma cell migration and survival and differentially regulates cell behavior relative to AXL. Pigment Cell Melanoma Res., 2013, 26, 527-541.

[79] Dugo, M.; Nicolini, G.; Tragni, G.; Bersani, I.; Tomassetti, A.; Colonna, V.; Del Vecchio, M.; De Braud, F.; Canevari, S.; Anichini, A.; Sensi, M. A melanoma subtype with intrinsic resistance to BRAF inhibition identified by receptor tyrosine kinases gene-driven classification. Oncotarget, 2015, 6, 5118-5133.

[80] Liu, L.; Greger, J.; Shi, H.; Liu, Y.; Greshock, J.; Annan, R.; Halsey, W.; Sathe, G.M.; Martin, A.M.; Gilmer, T.M. Novel mechanism of lapatinib resistance in HER2-positive breast tumor cells: activation of AXL. Cancer Res., 2009, 69, 6871-6878

[81] Giles, K.M.; Kalinowski, F.C.; Candy, P.A.; Epis, M.R.; Zhang, P.M.; Redfern, A.D.; Stuart, L.M.; Goodall, G.J.; Leedman, P.J. Axl mediates acquired resistance of head and neck cancer cells to the epidermal growth factor receptor inhibitor erlotinib. Mol. Cancer. Ther., 2013, 12, 25412558.

[82] Zhang, Z.; Lee, J.C.; Lin, L.; Olivas, V.; Au, V.; LaFramboise, T.; Abdel-Rahman, M.; Wang, X.; Levine, A.D.; Rho, J.K.; Choi, Y.J.; Choi, C.M.; Kim, S.W.; Jang, S.J.; Park, Y.S.; Kim, W.S.; Lee, D.H.; Lee, J.S.; Miller, V.A.; Arcila, M.; Ladanyi, M.; Moonsamy, P.; Sawyers, C.; Boggon, T.J.; Ma, P.C.; Costa, C.; Taron, M.; Rosell, R.; Halmos, B.; Bivona, T.G. Activation of the AXL kinase causes resistance to EGFR-targeted therapy in lung cancer. Nat. Genet., 2012, 44, 852-860.

[83] Rho, J.K.; Choi, Y.J.; Kim, S.Y.; Kim, T.W.; Choi, E.K.; Yoon, S.J.; Park, B.M.; Park, E.; Bae, J.H.; Choi, C.M.; Lee, J.C. MET and AXL inhibitor NPS-1034 exerts efficacy against lung cancer cells resistant to EGFR kinase inhibitors because of MET or AXL activation. Cancer Res., 2014, 74, 253-262.

[84] Suda, K.; Mizuuchi, H.; Sato, K.; Takemoto, T.; Iwasaki, T.; Mitsudomi, T. The insulin-like growth factor 1 receptor causes acquired resistance to erlotinib in lung cancer cells with the wild-type epidermal growth factor receptor. Int. J. Cancer, 2014, 135, 1002-1006.

[85] Wilson, C.; Ye, X.; Pham, T.; Lin, E.; Chan, S.; McNamara, E.; Neve, R.M.; Belmont, L.; Koeppen, H.; Yauch, R.L.; Ashkenazi, A.; Settleman, J. AXL inhibition sensitizes mesenchymal cancer cells to antimitotic drugs. Cancer Res., 2014, 74(20), 5878-5890. 
[86] Brand, T.M.; Iida, M.; Stein, A.P.; Corrigan, K.L.; Braverman, C.M.; Luthar, N.; Toulany, M.; Gill, P.S.; Salgia, R.; Kimple, R.J.; Wheeler, D.L. AXL mediates resistance to cetuximab therapy. Cancer Res., 2014, 74, 5152-5164.

[87] Elkabets, M.; Pazarentzos, E.; Juric, D.; Sheng, Q.; Pelossof, R.A.; Brook, S.; Benzaken, A.O.; Rodon, J.; Morse, N.; Yan, J.J.; Liu, M.; Das, R.; Chen, Y.; Tam, A.; Wang, H.; Liang, J.; Gurski, J.M.; Kerr, D.A.; Rosell, R.; Teixido, C.; Huang, A.; Ghossein, R.A.; Rosen, N.; Bivona, T.G.; Scaltriti, M.; Baselga, J. AXL mediates resistance to PI3Kalpha inhibition by activating the EGFR/PKC/mTOR axis in head and neck and esophageal squamous cell carcinomas. Cancer Cell, 2015, 27, 533-546.

[88] Kim, K.C.; Lee, C. Reversal of Cisplatin resistance by epigallocatechin gallate is mediated by downregulation of axl and tyro 3 expression in human lung cancer cells. Korean $J$. Physiol. Pharmacol., 2014, 18, 61-66.

[89] Hong, C.C.; Lay, J.D.; Huang, J.S.; Cheng, A.L.; Tang, J.L.; Lin, M.T.; Lai, G.M.; Chuang, S.E. Receptor tyrosine kinase AXL is induced by chemotherapy drugs and overexpression of AXL confers drug resistance in acute myeloid leukemia. Cancer Lett., 2008, 268, 314-324.

[90] Yoshida, T.; Zhang, G.; Smith, M.A.; Lopez, A.S.; Bai, Y.; Li, J.; Fang, B.; Koomen, J.; Rawal, B.; Fisher, K.J.; Chen, A.Y.; Kitano, M.; Morita, Y.; Yamaguchi, H.; Shibata, K.; Okabe, T.; Okamoto, I.; Nakagawa, K.; Haura, E.B. Tyrosine phosphoproteomics identifies both codrivers and cotargeting strategies for T790M-related EGFR-TKI resistance in non-small cell lung cancer. Clin. Cancer Res., 2014, 20, 4059-4074.

[91] Bae, S.Y.; Hong, J.Y.; Lee, H.J.; Park, H.J.; Lee, S.K. Targeting the degradation of AXL receptor tyrosine kinase to overcome resistance in gefitinib-resistant non-small cell lung cancer. Oncotarget, 2015, 6, 10146-10160.

[92] Hari, S.B.; Merritt, E.A.; Maly, D.J. Sequence determinants of a specific inactive protein kinase conformation. Chem. Biol., 2013, 20, 806-815.

[93] Liu, Y. and Gray, N.S. Rational design of inhibitors that bind to inactive kinase conformations. Nat. Chem. Biol., 2006, 2, 358-364.

[94] Suarez, R.M.; Chevot, F.; Cavagnino, A.; Saettel, N.; Radvanyi, F.; Piguel, S.; Bernard-Pierrot, I.; Stoven, V.; Legraverend, M. Inhibitors of the TAM subfamily of tyrosine kinases: synthesis and biological evaluation. Eur. J. Med. Chem., 2013, 61, 2-25.

[95] Davis, M.I.; Hunt, J.P.; Herrgard, S.; Ciceri, P.; Wodicka, L.M.; Pallares, G.; Hocker, M.; Treiber, D.K.; Zarrinkar, P.P. Comprehensive analysis of kinase inhibitor selectivity. Nat. Biotechnol., 2011, 29, 1046-1051.

[96] U.S. National Institute of Health. Available from: https://clinicaltrials.gov (Accessed November 15, 2015)

[97] Cortes, J.E.; Kim, D.W.; Kantarjian, H.M.; Brummendorf, T.H.; Dyagil, I.; Griskevicius, L.; Malhotra, H.; Powell, C.; Gogat, K.; Countouriotis, A.M.; Gambacorti-Passerini, C. Bosutinib versus imatinib in newly diagnosed chronicphase chronic myeloid leukemia: results from the BELA trial. J. Clin. Oncol., 2012, 30, 3486-3492.

[98] Vouri, M.; An, Q.; Birt, M.; Pilkington, G.J.; Hafizi, S. Small molecule inhibition of Axl receptor tyrosine kinase potently suppresses multiple malignant properties of glioma cells. Oncotarget, 2015, 6, 16183-16197.

[99] Zhao, H.; Luoto, K.R.; Meng, A.X.; Bristow, R.G. The receptor tyrosine kinase inhibitor amuvatinib (MP470) sensitizes tumor cells to radio- and chemo-therapies in part by inhibiting homologous recombination. Radiother. Oncol., 2011, 101, 59-65.

[100] Mita, M.; Gordon, M.; Rosen, L.; Kapoor, N.; Choy, G.; Redkar, S.; Taverna, P.; Oganesian, A.; Sahai, A.; Azab, M.; Bristow, R.; Tolcher, A.W. Phase 1B study of amuvatinib in combination with five standard cancer therapies in adults with advanced solid tumors. Cancer Chemother. Pharmacol., 2014, 74, 195-204.

[101] Sinha, S.; Boysen, J.; Nelson, M.; Secreto, C.; Warner, S.L.; Bearss, D.J.; Lesnick, C.; Shanafelt, T.D.; Kay, N.E.; Ghosh, A.K. Targeted Axl inhibition primes chronic lymphocytic leukemia B cells to apoptosis and shows synergistic/additive effects in combination with BTK inhibitors. Clin. Cancer Res., 2015, 21, 2115-2126.

[102] Wu, X.; Liu, X.; Koul, S.; Lee, C.Y.; Zhang, Z.; Halmos, B. AXL kinase as a novel target for cancer therapy. Oncotarget, 2014, 5, 9546-9563.

[103] Zhang, Y.X.; Knyazev, P.G.; Cheburkin, Y.V.; Sharma, K.; Knyazev, Y.P.; Orfi, L.; Szabadkai, I.; Daub, H.; Keri, G.; Ullrich, A. AXL is a potential target for therapeutic intervention in breast cancer progression. Cancer Res., 2008, 68, 1905-1915.

[104] Messoussi, A.; Peyronnet, L.; Feneyrolles, C.; Cheve, G.; Bougrin, K.; Yasri, A. Structural elucidation of the DFGAsp in and DFG-Asp out states of TAM kinases and insight into the selectivity of their inhibitors. Molecules, 2014, 19, 16223-16239.

[105] Paolino, M.; Choidas, A.; Wallner, S.; Pranjic, B.; Uribesalgo, I.; Loeser, S.; Jamieson, A.M.; Langdon, W.Y.; Ikeda, F.; Fededa, J.P.; Cronin, S.J.; Nitsch, R.; SchultzFademrecht, C.; Eickhoff, J.; Menninger, S.; Unger, A.; Torka, R.; Gruber, T.; Hinterleitner, R.; Baier, G.; Wolf, D.; Ullrich, A.; Klebl, B.M.; Penninger, J.M. The E3 ligase Cbl-b and TAM receptors regulate cancer metastasis via natural killer cells. Nature, 2014, 507, 508-512.

[106] Traore, T.; Cavagnino, A.; Saettel, N.; Radvanyi, F.; Piguel, S.; Bernard-Pierrot, I.; Stoven, V.; Legraverend, M. New aminopyrimidine derivatives as inhibitors of the TAM family. Eur. J. Med. Chem., 2013, 70, 789-801.

[107] Liu, J.; Yang, C.; Simpson, C.; Deryckere, D.; Van Deusen, A.; Miley, M.J.; Kireev, D.; Norris-Drouin, J.; Sather, S.; Hunter, D.; Korboukh, V.K.; Patel, H.S.; Janzen, W.P.; Machius, M.; Johnson, G.L.; Earp, H.S.; Graham, D.K.; Frye, S.V.; Wang, X. Discovery of novel small molecule mer kinase inhibitors for the treatment of pediatric acute lymphoblastic leukemia. ACS Med. Chem. Lett., 2012, 3, 129134.

[108] Da, C.; Stashko, M.; Jayakody, C.; Wang, X.; Janzen, W.; Frye, S.; Kireev, D. Discovery of Mer kinase inhibitors by virtual screening using Structural Protein-Ligand Interaction Fingerprints. Bioorg. Med. Chem., 2015, 23, 10961101.

[109] Christoph, S.; Deryckere, D.; Schlegel, J.; Frazer, J.K.; Batchelor, L.A.; Trakhimets, A.Y.; Sather, S.; Hunter, D.M.; Cummings, C.T.; Liu, J.; Yang, C.; Kireev, D.; Simpson, C.; Norris-Drouin, J.; Hull-Ryde, E.A.; Janzen, W.P.; Johnson, G.L.; Wang, X.; Frye, S.V.; Earp, H.S.,3rd; Graham, D.K. UNC569, a novel small-molecule mer inhibitor with efficacy against acute lymphoblastic leukemia in vitro and in vivo. Mol. Cancer. Ther., 2013, 12, 2367-2377.

[110] Janning, M.; Ben-Batalla, I.; Loges, S. Axl inhibiton: a potential road to a novel acute myeloid leukemia therapy? Expert Rev. Hematol., 2015, 8(2), 135-138. 